\title{
Epithelial Cell-Transforming Sequence 2 Oncogene-Like
}

National Cancer Institute

\section{Source}

National Cancer Institute. Epithelial Cell-Transforming Sequence 2 Oncogene-Like. NCI Thesaurus. Code C101454.

Epithelial cell-transforming sequence 2 oncogene-like (904 aa, $105 \mathrm{kDa}$ ) is encoded by the human ECT $2 \mathrm{~L}$ gene. This protein may be involved in signal transduction. 